\title{
Current Management Situation of renowned Sporting equipment enterprises in China --Take Li Ning Sports Goods Co., Ltd. as an example
}

\author{
Gu Yue, Mohamad Hisyam Selamat and Lyu XiaDi
}

Institute of Graduate Studies, Segi University, Kota damansara, Selangor, Malaysia.

\begin{abstract}
Sports industry is a sunrise industry in China. The development of Listed enterprises in the sports industry has gradually become an important symbol of the development and competitiveness of China's sports industry. This paper takes Li Ning Sports Goods Listed Company as the research object, describes the characteristics of management of sports listed companies, and systematically expounds the inevitability of management of sports listed companies, points out the main problems and put forward the improvement countermeasures, so as to provides suggestions for the continuous improvement of sports goods listed companies in China.
\end{abstract}

Key words: sporting goods, management strategy, listed corporations.

\section{INTRODUCTION}

With the rapid development of economic globalization and the popularization of sports in all countries of the world, the sports industry is becoming the most promising new industry in the century. From sports competition industry to mass fitness industry, sports goods industry to sports tourism and sports lottery industry, from sports advertisers to sports sponsors in sports intermediary industry, the sports industry has penetrated into people's daily life and merged into the ever-changing economic relations. Whether developed countries in Europe and the United States or emerging developing countries such as China and India, the emergence of the tertiary industry, especially the great development of sports industry, which belongs to the tertiary industry, has become an important indicator of a country's economic development. As the pillar industry of the sports industry, sports goods industry has also achieved huge development [1]. In 2018, China's total import and export of sports goods was about 23.450 billion US dollars, of which 22.322 billion yuan was exported, accounting for $95.19 \%$ of the total import and export. With the establishment of the 13th FiveYear Plan, improving people's living standards and quality will make people pay more attention to the pursuit of health, the national fitness boom continues to heat up, and the sports goods market shows an unpredictable large demand [2].

\section{LITERATURE REVIEWS}

\section{Concept of Sports Goods Enterprises}

Sports goods manufacturing industry is the largest and fastest growing sports industry. However, there is not a unified standard for defining the concept of sports goods enterprises, which involves companies of sports clothing, sports shoes, and hats, sports functional health drinks, sports food and so on. Sports goods enterprises are also divided into corporations of sports ball, sports protective equipment, fitness training equipment and various other types of sports goods [3]. The lack of a unified standard caliber in the definition of the concept is not

Corresponding Author: Gu Yue, Institute of Graduate Studies, Segi University, Kota damansara, Selangor, Malaysia, 15503512467@163.com 
conducive to the classification and integration of sports goods enterprises, nor is it conducive to convergence with the world sports goods enterprises. To fully reflect the development status and trend of sports goods manufacturing enterprises, sports goods enterprises should be clearly defined. In this paper, sporting goods enterprises refer to enterprises engaged in manufacturing and marketing products, which is also the form of most sporting goods enterprises in China [4].

\section{Research on Sports Goods Industry Abroad}

Under the background of economic globalization, the situation and pattern of the world sporting goods industry have undergone profound changes. Major brands have launched fierce market competition around scale expansion, technological innovation, brand strategy, intellectual property rights and trade protection [5]. The wide application of high-tech and new materials also forms a new technological monopoly. Globalization of the sports market has been formed, and foreign scholars have invested in the research of the sports market. [6].Through the analysis of the collected foreign literature, the research of foreign sports goods industry mainly focuses on the following aspects: the research of globalization development. Matthew [7] made a systematic study on the global development of NIKE and other international brands; Alves and Bergmark [8], "The origin of Adidas, brand development, brand value, the reasons for the sharp decline of brands, and the return of brands to glory and dreams are systematically elaborated. Casillas and Espinosa [9] explored the monopoly of international brands such as NIKE on the Canadian sports market and the consequent strangling of Canadian local sports goods brands. In order to solve the problem of "gradual decline" of sports goods industry in the United States, the report "Made in the United States from gradual decline to the revitalization of the strong wind" was made. The changes in the global manufacturing market structure were analyzed in detail, and the competition strategy for the future market of sports goods industry in the United States represented by Nike was formulated. More and more countries start from the market structure of sports goods manufacturing industry and subdivide the sports goods market[10]. Hailin [11] conducted a profound and comprehensive study on the important issues such as investment and financing, cost control and income-generating methods in the development of sports enterprises through the scale of the economic development of sports industry and the factors that have an impact on the growth of the sports industry.

\section{Research on Sports Goods Industry in China}

Qiao and Liu [12] analyzed the current situation, characteristics, and advantages of China's Sports Goods Industry Cluster, pointing out that China's Sports Goods Industry Cluster mainly concentrates in Guangdong, Fujian, Jiangsu, Zhejiang and Shanghai provinces (cities), and most of the sports goods enterprises mainly focus on the same product. Or closely related products are engaged in product development, production and marketing; a production and management pattern of "one town (township) one product" is formed with the characteristics of specialization of industrial layout, intensive production of products and socialization of production cooperation; Sports goods industry cluster has advantages of scale and cost, information and innovation, region and brand, industry and market, policy and environment.

Xiao [13] takes Jinjiang Sports Footwear Industry Cluster in Fujian Province as an example to illustrate the practical significance of developing sports goods industry cluster, puts forward relevant suggestions for the development of China's sports goods industry cluster, and points out that the effect of the sports goods industry cluster should be brought into full play, the content of product science and technology should be improved, and the brand resources of industrial 
cluster should be imported. Integration should be carried out to build a strong brand of China's sports goods industry.

\section{Research on International Competitiveness of Sports Goods}

The present situation of our country is that the quantity of labor force is large and the price is low. Under such circumstances, the sports industry as a labor-intensive industry has developed rapidly in our country, and our country has become the base of producing sports goods in the world. The famous international brands Nike, Adidas and so on have established production bases in China, and the output of our country accounts for the majority of its total production. Although our country has such production capacity, the value of sports brand belonging to our country is very low [14].

$\mathrm{Su}$ [15] considered that the international competitiveness of China's sporting goods was influenced by factors of production, demand conditions, related and supporting industries, enterprise strategy and competition structure of the same industry, government and opportunity, and through the situation of International competitiveness of Chinese and foreign sporting goods. The comparative analysis shows that although Chinese sporting goods occupy a larger share in the international market, as far as a single sporting goods enterprise is concerned, there is a big gap between them in product positioning, R\&D, design, development strategy, product price and other aspects, such as Nike and Adidas. It is suggested that in order to improve the international competitiveness of Chinese sporting goods enterprises, they should focus on brand shaping, create brand characteristics and put it at the core of the competitiveness of enterprises [16].

Research on the Management of Sports goods Listed Companies

Zhan [17] took 17 sports industry listed companies as samples, selected financial indicators of earnings per share, total assets return, net assets return and net profit growth rate, and explored the differences in performance between diversified and non-diversified management in sports listed companies. The results showed that diversified companies did not achieve significant differences in performance. The reason for diversification lies in enhancing the strategic competitiveness and scale effect of enterprises. Therefore, sports listed companies need to further strengthen their main business and effectively carry out portfolio management. Lu [18] used the method of documentation and logical analysis to study the marketing strategies of 5 listed companies of sports goods in Quanzhou. That paper analyzed the target orientation, consumption objects, common and differentiated integrated marketing strategies of listed companies of sports goods in Quanzhou, and put forward individualized demand, market segmentation, and high technology as the backing.

\section{METHODOLOGY}

Through the SEGI University Library, China Knowledge Network CNKI Digital Library and other sports websites, a large number of journal articles, web pages and company annual reports related to this article were collected, which provided a wide range of data sources for the writing of the paper; It also consulted various data and policies and other guiding documents on sports goods enterprises in the National Bureau of Statistics, the General Administration of Sports and related websites, which provided a reliable basis for the comprehensiveness and authenticity of the content of the paper. This paper also uses a combination of logic analysis, mathematical statistics to compare and analyze the financial data disclosed publicly in the annual reports of sports listed companies, calculates the data needed for the evaluation index, and analyses the operation status of listed companies through the statistical results. 


\section{RESULT ANALYSES AND DISCUSSIONS \\ Basic Situation of Sports Goods Listed Companies in China}

In June 2004, Li Ning was listed on the Hong Kong Stock Exchange and became the first sports goods listed company in China. In the following years, 11 sports goods companies listed in Hong Kong, domestic A shares, Singapore and the United States.

By 2018, total equity of Li Ning Sports Goods Listed Companies was 219 million shares and total assets were 31.3 billion. Its main business content involves sports clothing, sports shoes, fitness equipment and so on.

If an enterprise wants to develop rapidly, it must have sufficient funds. The best way to obtain funds is to raise funds from the secondary market by issuing shares [19]. After listing, Li Ning Sports Goods Listed Company raised a large number of social funds through the capital market, which not only solved the problem of fund shortage in the process of company development but also laid a foundation for the company to expand rapidly. At the same time, it also promoted the development and growth of China's sports goods industry and created conditions for China's sports goods industry to improve its international competitiveness [20]. Li Ning's new shares were listed in 2004 and raised $\mathrm{HK} \$ 440$ million, mainly for the following purposes: about HK $\$ 100$ million for expansion and improvement of distributors and retail networks; about HK\$110 million for promotion and brand promotion; about HK\$115 million for product design and development; HK\$135 million for upgrading management information systems and logistics business; and about $\mathrm{HK} \$ 140$ million for acquisition and operation of other international products. The management or franchise of the license in the Chinese market; about HK\$0.6 billion to set up an operation center in Beijing; and other funds are used for strategic acquisitions when opportunities arise [21].

\section{Management Strategy of Sports Goods Listed} Companies in China

For a long time, Li Ning Co., Ltd. has always adhered to its core strategy and mission: focusing on brand promotion and product innovation to achieve differentiated competition; focusing on the essence of sports to stimulate people's desire and strength to break through. After years of development, the company has established a large-scale distribution and retail network in China [22]. In order to consolidate and enhance Li Ning's position as a leading sports brand in China, the company has taken the following operational measures:

In 2018, the Group adopted the development strategy of "single brand, multi-category, and multi-channel", and managed multi-sports categories under the core main brand of "Li Ning", which made each category form its own business platform. At the same time, we should make full use of the synergistic effect in the product, channel, retail operation, and supply chain management to build and consolidate Li Ning experience value [23].

At the same time, the Group actively optimizes the channel structure and promotes channel efficiency. We should adopt diversified development strategies, close and reform inefficient and loss-making stores, and increase the number of efficient stores. At the same time, the Group continues to innovate the image matrix of stores. The brand-new image of $\mathrm{Li}$ Ning Fashion Shop in China is first introduced. It mainly distributes in the high-end business circles of super-large to second-tier cities to attract young fashionable consumers [20].

In addition, as of December 31, 2018, the number of $\mathrm{Li}$ Ning sales points (excluding $\mathrm{Li}$ Ning YOUNG) in the Chinese market totaled 6,344, with a net increase of 82 points in the year to date. the retail business decreased by 35 and the wholesale business increased by 117 . Distributors' confidence continues to grow. At the latest order meeting held in December 2018, 
licensing distributors' orders for Li Ning brand products (excluding Li Ning YOUNG) recorded a low growth rate of $10 \%$ to $20 \%$ per year [23]. In addition to the Li Ning brand, the group also actively expands new business, making its brand portfolio more diversified. 2018 is a year of increasing scale and strengthening fine management of YOUNG in Li Ning. It builds a healthy development retail business model with products to meet consumer demand as the core and retail profit as the driving force. In terms of products, YOUNG Li Ning has continued to invest and innovate in product themes and technological performance. It has launched fashion products such as fashion week parentchild model, BADFIVE, Disney Co-operative model and other fashion products. Meanwhile, it has launched seasonal products with technological performance to enhance the technological attributes of products. In the aspect of channel retailing, we should continue to accelerate the expansion of channel customers and stores, and continue to upgrade the image of stores. In 2018, YOUNG has covered 30 provinces with 793 stores (2017: 173stores) [24].

\section{Performance of Sports Goods Listed Companies in China}

Economic performance mainly refers to the evaluation of efficiency related to economic and resource allocation and resource utilization. Performance evaluation refers to the use of mathematical statistics and operational research methods, the use of specific indicators system, the comparison of unified evaluation standards, according to certain procedures, through quantitative and qualitative comparative analysis, to make an objective, fair and accurate comprehensive evaluation of the operating efficiency and operator performance of an enterprise during a certain period of operation.

Table 1 Performance Evaluation Indicators of Sporting Good

\begin{tabular}{ll}
\hline Categories of indicators & Evaluation index \\
\hline Profitability & Return on Total Assets, Shareholders' Equity \\
Operational capacity & Total asset turnover rate \\
Solvency & Asset-liability ratio, current ratio \\
Growth Ability & Gross Asset Growth Rate, Operating Income Growth Rate, Net Profit \\
& Growth Rate
\end{tabular}

In order to accurately and comprehensively analyze and evaluate the operating conditions of sports goods listed companies in China, this paper, based on the characteristics of sports goods listed companies, synthesizes the research of domestic and foreign scholars, refers to the "Rules for the Operation of Enterprise Performance Evaluation", defines the performance evaluation indicators of sports goods according to the financial data published in the annual reports of companies (see table 1). The evaluation indexes are classified and counted.

\section{Profitability}

From 2016 to 2018, the total asset profit margins of Li Ning Sports Goods Company are $16.63 \%$, $12.56 \%$, and $14.89 \%$ respectively. From 2016 to 2018 , the returns on shareholders' equity of $\mathrm{Li}$ Ning Sports Goods Company are 39.62\%, $41.33 \%$, and $36.68 \%$ respectively. From 2016 to 2018, the profit margin of Li Ning's total assets is about $13 \%-17 \%$. The higher value indicates that the company's overall profitability is strong and stable, and the return rate of shareholders' rights and interests is higher than $35 \%$ in three years 
[25]. It also shows that the company has strong profitability, good asset utilization efficiency, and high management level.

\section{Operational capacity}

The total asset turnover rates of Li Ning Sports Goods Company in the past three years are 187.98, 172.66 and 158.77 (units: times). Li Ning's total asset turnover rate in the past three

years is at a very high level, with an annual surrounding rate of more than 150 times, indicating that the company's assets from input to output turnover speed is very fast, capital utilization efficiency is high, and operating ability is excellent [26]. However, the company's turnover slowed down slightly, which was mainly due to the impact of the terminal retail market, dealers cash turnover slowed down.

\section{Solvency}

The asset-liability ratio of Li Ning Sports Goods Company in recent three years is $41.05 \%, 40.70 \%$, and $33.32 \%$ respectively. The current ratio of $\mathrm{Li}$ Ning Sports Goods Company in the past three years is $1.35,1.7$ and 1.77 respectively (unit: times). Li Ning's asset-liability ratio dropped from $41.05 \%$ in 2016 to $40.70 \%$ in 2018 , showing a slight downward trend, basically maintaining a relatively stable debt level. Li Ning's liquidity ratio increased from 1.35 in 2016 to 1.77 in 2018 , showing a slight upward trend, indicating that $\mathrm{Li}$ Ning's short-term solvency has gradually increased [26].

\section{Growth ability}

The total assets growth rate of Li Ning Sports Goods Company in recent three years is $13.10 \%$, $10.71 \%$, and $18.30 \%$ respectively. The growth rate of Li Ning Sports Goods Company's business income in the past three years is $13.06 \%, 10.71 \%$, and $18.45 \%$ respectively. The net profit growth rates of Li Ning Sports Goods Company in the past three years are $16.10 \%, 10.16 \%$, and $12.30 \%$ respectively [25].
Combined with the above three indicators, $\mathrm{Li}$ Ning's total assets scale has increased year by year. Due to the financial crisis and the competitive pressure of international brands, the growth rate has slowed down but still maintained growth. These three indicators show that the overall growth of Li Ning Company is good and its development ability is strong.

\section{Li Ning Sporting Goods Company's problems in its operation}

Li Ning Company uses outsourcing mode to produce, the main production factories are in China. With the development of China's economy, labor price and raw material cost are also increasing, which brings higher cost pressure to the production of Li Ning's products. After Nike, Adidas and other international brands have stabilized the high-end market, they are now beginning to extend the middle and low-end market, which will inevitably lead to a positive market conflict with Li Ning. According to their strength and brand influence, it is inevitable to win some of Li Ning's purchasing customers. At the same time, other local low-end brands also extend to the mid-range market, which makes the competition in the mid-range market particularly fierce, which is a great threat to Li Ning's market share [27].

The Jinjiang Sports Goods Corps headed by Anta and Peak rose rapidly in China, breaking the dominant pattern of Li Ning brand in the national brand of Chinese sports goods. Although Li Ning brand is still in the leading position of a national brand of sporting goods with stronger brand awareness and influence, better product quality and more high-tech content, other local sporting goods companies have attracted many consumers with lower prices and occupied a large market share in the middle and low-end market. In particular, Anta brand has launched a strong challenge to Li Ning. The high-end market of $\mathrm{Li}$ Ning brand is hindered by the first-class international brands, while the low-end market is 
facing challenges from other domestic sports goods brands. Li Ning Company started brand internationalization very early, but the pace of brand internationalization is too fast, which consumes a lot of energy and resources. On the contrary, its internationalization has not achieved good results and has been surpassed by international sports brand companies [28].

\section{CONCLUSIONS}

China's sporting goods industry as a whole is still in a relatively low-end position in the global value chain. The small scale of enterprises, poor innovation ability, low brand influence, and the need to improve product competitiveness restrict the development and growth of China's sporting goods enterprises. At the same time, trade barriers arising from the process of world integration continue to slow the pace of Chinese sporting goods companies going global. Chinese sports goods enterprises should learn from international famous sports brand companies in market positioning, design and research, supplier relationship, retail channel management, and so on. They should strengthen their R\&D capabilities, continuously deliver the best costeffective products with high-tech content to the market, continuously increase R\&D investment, put forward higher $R \& D$ requirements for products, precisely locate the target market and provide professional services.

\section{REFERENCES}

[1] Ding,H.(2018).Current situation and Countermeasures of sports goods industry in China. Special Economic Zone (3).

[2] Liu,G.Y. (2016). Thoughts on the Development of National Fitness in the 13th Five-Year Plan Period. Journal of Beijing Sports University, 39 (10), 1-11.

[3] Li,W. (2006). Research on Brand Management of Li Ning Sporting Goods Company. (Doctoral dissertation, University of Foreign Economics and Trade).
[4] Jiang,J.(2012). Research on marketing management innovation of Li Ning Sports Goods Company. (Doctoral dissertation, Guangxi University).

[5] Rubleske, J., \& Berente, N. (2017). A pragmatist perspective on entrepreneurial opportunities. International Journal of Innovation Science, 9(2), IJIS-09-2016-0031.

[6] Dong X.J. (2013). Application of modern new material technology in sports. Contemporary sports science and technology (03), 123-124.

[7] Elsmore, \& James, M. (2000). The implications of intellectual property law for the auditing and protection of national and international brands: part ii. brands in the grey market. Managerial Auditing Journal, 15(4), 169-181.

[8] Alves, J. S., Bergmark, T., Bunyagidj, C., Scholtens, B., Kituyi, E., \& Mazurek, J., et al. (2007). Experts address the question: How has the globalization of industrial supply chains impacted sustainable development in developing countries?. Natural Resources Forum.

[9] Casillas, L., Espinosa, F. J., HuertaQuintanilla, R., \& Rodriguez-Achach, M. (2006). Condensation in an economic model with brand competition. International Journal of Modern Physics C, 17(05), 749-756.

[10] Baron, D. A., Martin, D. M., \& Abol, M. S. (2007). Doping in sports and its spread to atrisk populations: an international review. World Psychiatry Official Journal of the World Psychiatric Association, 6(2), 118.

[11] Hailin. (2016). Inspiration of successful experience of U.S. and European enterprises leveraging sports marketing on "going global" of Chinese enterprises. Sports science: English version (4), 250-255.

[12] Qiao, B., Liu, W., \& Xiang, T. (2010). The path analysis of innovation networks construction of china"s equipment manufacturing industry cluster. Advanced Materials Research, 171-172, 636-639. 
Gu Yue et al./ International Journal of Business and Management, 3(6) 2019, Pages: 08-15

[13] Xiao, Z. M. (2011). Research on regional brand evolution model of Jinjiang sports characteristic industry. Journal of Anhui Agricultural University (Social Science Edition), 20 (1), 61-64.

[14] Hu,S.X., \& Yang,S.P. (2016). Research on the Core Competitiveness of Sports Goods Enterprises in China. Journal of Wuhan Institute of Physical Education, 40 (6), 45-48.

[15] Su,Y.Q. (2012). Current situation, problems and Countermeasures of sports goods market development in China. Market modernization (23), 62-62.

[16]Xu, F., Tang, J. X., \& Wang, H. W. (2016). Financing Analysis of China's Sports Shoes and Clothing Listed Companies in the PostOlympic Era: Based on Product Diversity and Market Competition Research. Sports Science, 36(2), 80-91.

[17] Zhan, X. H. (2013). The Impact of Working Capital Structure of Chinese Sports Industry Listed Companies on Enterprise Performance: An Empirical Study of 17 Sports Industry Listed Companies in China. Journal of Wuhan Institute of Physical Education, 47 (9), 28-34.

[18] Lu, Z. Y. (2010). An Empirical Study on the Upgrading of Quanzhou Sporting Goods Industry in the Global Value Chain: Taking Five Listed Companies as an Example. Enterprise Economy (2), 131-134.

[19] Ren, B., \& Dai, J. (2017). Empirical Study on the Competitiveness of Chinese Sports Industry Listed Companies. Sports Science Research, 21 (2), 38-42.

[20] Liu, C.H., Zhang,S.X., \& Li, X.F. (2012). Efficiency evaluation of Chinese and foreign sports listed companies based on Three-stage DEA model. Sports Science, 32 (10), 20-26.

[21] Song, B. (2013). Research on Capital Management of Sports Listed Companies in
China. (Doctoral dissertation, Nanjing Normal University)

[22] Zhong, N., \& Zhao, X. L. (2017). Research status and suggestions of listed sports companies in China. Journal of Harbin Institute of Physical Education, 35 (5), 62.

[23] Wang, Z. H., Zhong, H.M., \& Zhan, W. (2018). An Empirical Study on the Impact of Innovative Ability on the Competitiveness of Sports Goods Enterprises in China. Journal of Beijing Normal University (Natural Science Edition) (4), 433-440.

[24] Gong,S.J., \& Lu,Q.H. (2018). Research on the Construction and Forecast of Growth Index System of Sports Goods Industry in China - Based on R Language Data Analysis. Journal of Shenyang Institute of Physical Education, 37(3), 21-28.

[25] Wang,B.X. (2018). Research on the operating performance of Listed Companies in China's sports industry sector - based on principal component analysis model. Productivity study, No. 307 (2), 138-142.

[26] Tan,H. (2018). An Empirical Study on the Impact of Competitive Strategy on the Performance of Sports Industry Listed Companies. Journal of Shanghai Institute of Physical Education, 42 (2).

[27] Wu,Y.N., Chen,Z., \& Li,J.J. (2010). Brand Competitiveness Evaluation of China Sports Goods Listed Companies - Based on Financial Statement Analysis. Sports Science, 30 (1), 30-35.

[28] Li,B.J, Chen,R.F, Wang,Z.Z, \& Yang,S.X.(2018). Driving factors and innovative modes of service-oriented manufacturing of sports goods in Fujian Province: A case study of Anta. Journal of Fujian Normal University (Philosophy and Social Sciences Edition) (1), 46-56. 